\title{
Antarctica ice sheet basal melting enhanced by high mantle heat
}

\author{
Irina M. Artemieva ${ }^{a, b, c, d, *}$

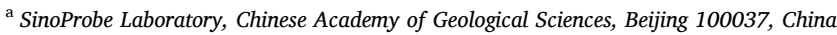 \\ ${ }^{\mathrm{b}}$ Marine Geodynamics, GEOMAR Helmholtz Center for Ocean Research, Kiel 24148, Germany \\ c State Key Laboratory GPMR, School of Earth Sciences, China University of Geosciences, Wuhan 430074, China \\ ${ }^{\mathrm{d}}$ Department of Geophysics, Stanford University, Stanford, CA 94305, USA
}

\section{A R T I C L E I N F O}

\section{Keywords:}

Ice-sheet collapse

Ice basal melting

Melt lubrication

Lithosphere thickness

Geothermal flux

\begin{abstract}
A B S T R A C T
Antarctica is losing ice mass by basal melting associated with processes in deep Earth and reflected in geothermal heat flux. The latter is poorly known and existing models based on disputed assumptions are controversial. Here I present a new geophysical model for lithospheric thickness and mantle heat flux for the entire Antarctica and demonstrate that significant parts of the East Antarctica craton have lost the cratonic lithosphere signature and the entire West Antarctica has a highly extended lithosphere, consistent with its origin as a system of back-arc basins. I conclude that the rate of Antarctica ice basal melting is significantly underestimated: (i) the area with high heat flux is double in size and (ii) the amplitude of the high heat flux anomalies is $20-30 \%$ higher than in previous results. Extremely high heat flux $\left(>100 \mathrm{~mW} / \mathrm{m}^{2}\right)$ in almost all of West Antarctica, continuing to the South Pole region, and beneath the Lake Vostok region in East Antarctica requires a thin $(<70 \mathrm{~km})$ lithosphere and shallow mantle melting, caused by recent geodynamic activity. This high heat flux may promote sliding lubrication and result in dramatic reduction of ice mass, such as in Heinrich events. The results form basis for reevaluation of the Antarctica ice-sheet dynamics models with consequences for global environmental changes.
\end{abstract}

\section{Introduction}

Climate change effects promote melting of ice-sheets from the top, but near-surface thermal perturbations cannot propagate deep into the ice due to low thermal conductivity. The impact of atmospheric warming on surface melting of the Antarctica ice-sheet is debated (DeConto and Pollard, 2016; Hanna et al., 2020). The main loss of ice mass in Antarctica is thought to happen through ice dynamics (Blankenship et al., 1993; Pritchard et al., 2012). Thermal anomalies at the ice-rock interface caused by geodynamic processes in the Earth's interior may cause basal melting of ice-sheets. Close to coast lines it may lead to a dramatic reduction of ice mass even at low melting rates by promoting ice sliding to the ocean through lubrication of the ice-rock interface (Blankenship et al., 1993).

Indeed, episodic massive break-offs of large ice masses are documented in the North Atlantic (Heinrich, 1988; Bond et al., 1992), where the so-called Heinrich events have an apparent periodicity of few thousand years (Bond and Lotti, 1995). Ice-sheet warming by geothermal heat is one of the proposed triggering mechanisms by which sub-glacial unconsolidated sediment and ice thaw to form a "slippery lubricant" layer at the base of the ice-sheet (MacAyeal, 1992; Marcott et al., 2011). The extremely fast onset of Heinrich events on time-scale of years (Maslin et al., 2001) makes them particularly important as potential triggers of global climate change (Blunier and Brook, 2001; Broecker, 2002; Hemming, 2004) with possible effects on the global ocean circulation (Sachs and Anderson, 2005).

Detailed studies of ice mass loss in Antarctica since 1992 demonstrate that while the East Antarctica ice-sheet has a nearly constant mass, although the details differ (Shepherd et al., 2018; Rignot et al., 2019), the rate of ice mass loss in West Antarctica has tripled (Shepherd et al., 2018). Therefore, ice dynamics in West Antarctica is a matter of primary concern for estimating global environmental consequences of ice-sheet melting, including global changes in the ocean salinity (Golledge et al., 2019) and in the sea-level (Mitrovica et al., 2009; DeConto and Pollard, 2016). However, up-to-date, heat flux supplied to the ice base from the Earth's interior is poorly constrained by geophysical and glaciological methods, particularly in West Antarctica.

\footnotetext{
* Correspondig author at: SinoProbe Laboratory, Chinese Academy of Geological Sciences, Beijing 100037, China.

E-mail address: iartemieva@geomar.de.
} 


\section{Previous models of geothermal heat flux in Antarctica}

\subsection{Large-scale geophysical models}

Seismic and magnetic constraints on the lithosphere thermal regime in the two contrasting geodynamic domains of Antarctica (Fox Maule et al., 2005; An et al., 2015; Martos et al., 2017; Haeger et al., 2019; Lösing et al., 2020) are hampered by physical assumptions in mathematical formulations, and they have not been thoroughly tested in regions where geothermal heat flux is known from conventional borehole measurements. The critical assumption of steady-state conductive heat flux through the lithosphere to the bedrock surface is likely to be valid in most of the tectonically stable East Antarctica (Fig. 1). However, rifting proposed for some parts of East Antarctica (Ferraccioli et al., 2011) invalidates the approach in the area around the Gamburtsev Mountains and the Lambert Rift, whereas the assumption of laterally constant thermal properties of the crust, including radioactive heat production, is not satisfied anywhere and leads to large potential errors (Lösing et al., 2020).

Some of the extreme heat production values (Carson et al., 2014) reported for the granitic outcrops in East Antarctica (the Prydz Bay, Fig. 1) suggest local short-wavelength heat flow variations. Such highamplitude local anomalies contribute to globally uncorrelated values of the heat flux and the Curie depth on continents (Li et al., 2017). Furthermore, heat flux models based on the steady-state heat conduction assumption (Fox Maule et al., 2005; An et al., 2015; Martos et al., 2017; Haeger et al., 2019; Lösing et al., 2020) (Fig. 2b,d,e) are invalid for the tectonically active West Antarctica, which has a broadly distributed recent tectono-magmatic activity (Blankenship et al., 1993; Behrendt, 1999) and is interpreted to represent either one of the largest continental rift systems (Behrendt, 1999) or a large system of back-arc basins (Artemieva and Thybo, 2020).

A probabilistic estimate of Antarctica heat flux based on correlation between a global surface wave seismic tomography model and measured heat flux on continents is particularly poorly constrained in West Antarctica (Fig. 2a), where the model has lateral resolution between 600 and $1000 \mathrm{~km}$, while standard deviation of heat flux exceeds $40 \mathrm{~mW} / \mathrm{m}^{2}$ and reaches $\sim 80 \mathrm{~mW} / \mathrm{m}^{2}$ in Marie Byrd Land (Shapiro and Ritzwoller, 2004). A similar recent study (Shen et al., 2020) based on correlation between seismic shear wave velocity anomalies and measured heat flux in the continental USA provides a probabilistic estimate of Antarctica heat flux at a higher lateral resolution and with a nominal model uncertainty of about $20 \mathrm{~mW} / \mathrm{m}^{2}$ (Fig. 2c). However, it is the only heat flux model that does not report heat flux greater than $85 \mathrm{~mW} / \mathrm{m}^{2}$ anywhere in Antarctica, including its western part, possibly because the critical assumption on structural similarity between the two continents is not satisfied. In particular, the continental USA lacks regions with the anomalous, 20-25 km thick, crust (Chulick and Mooney, 2002) as in large parts of West Antarctica (c.f. Behrendt, 1999; Artemieva and Thybo, 2020) (Supplementary Fig. S1).

Another class of geophysical models constrains Antarctica's heat flux based on correlations between crustal ages, lithosphere geotherms and lithosphere thickness, which are controlled by heat flux. A global continental thermal model (Artemieva, 2006) based on such correlations

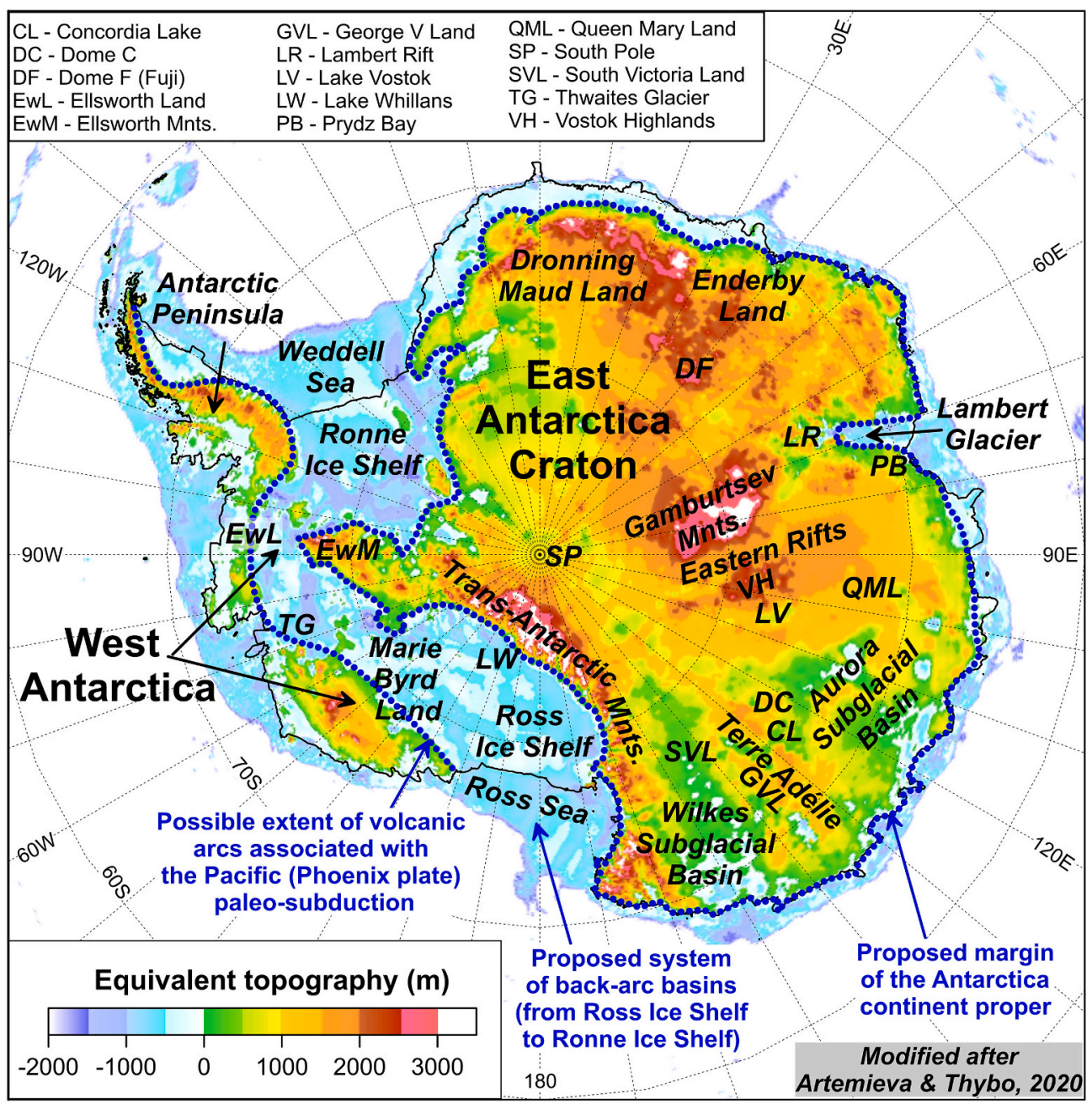

Fig. 1. Equivalent topography (calculated by reducing thicknesses of ice (Fretwell et al., 2013) with density of $920 \mathrm{~kg} / \mathrm{m}^{3}$ and water with density of $1020 \mathrm{~kg} / \mathrm{m}^{3}$ to bedrock density of $2670 \mathrm{~kg} / \mathrm{m}^{3}$ ). Blue dotted lines outline the boundaries of the proposed extent of the Antarctica continent proper in the east, volcanic arcs associated with the Pacific (Phoenix) plate paleo-subduction in the east, and the system of back-arc basins of West Antarctica in-between (Artemieva and Thybo, 2020). (For interpretation of the references to color in this figure legend, the reader is referred to the web version of this article.) 

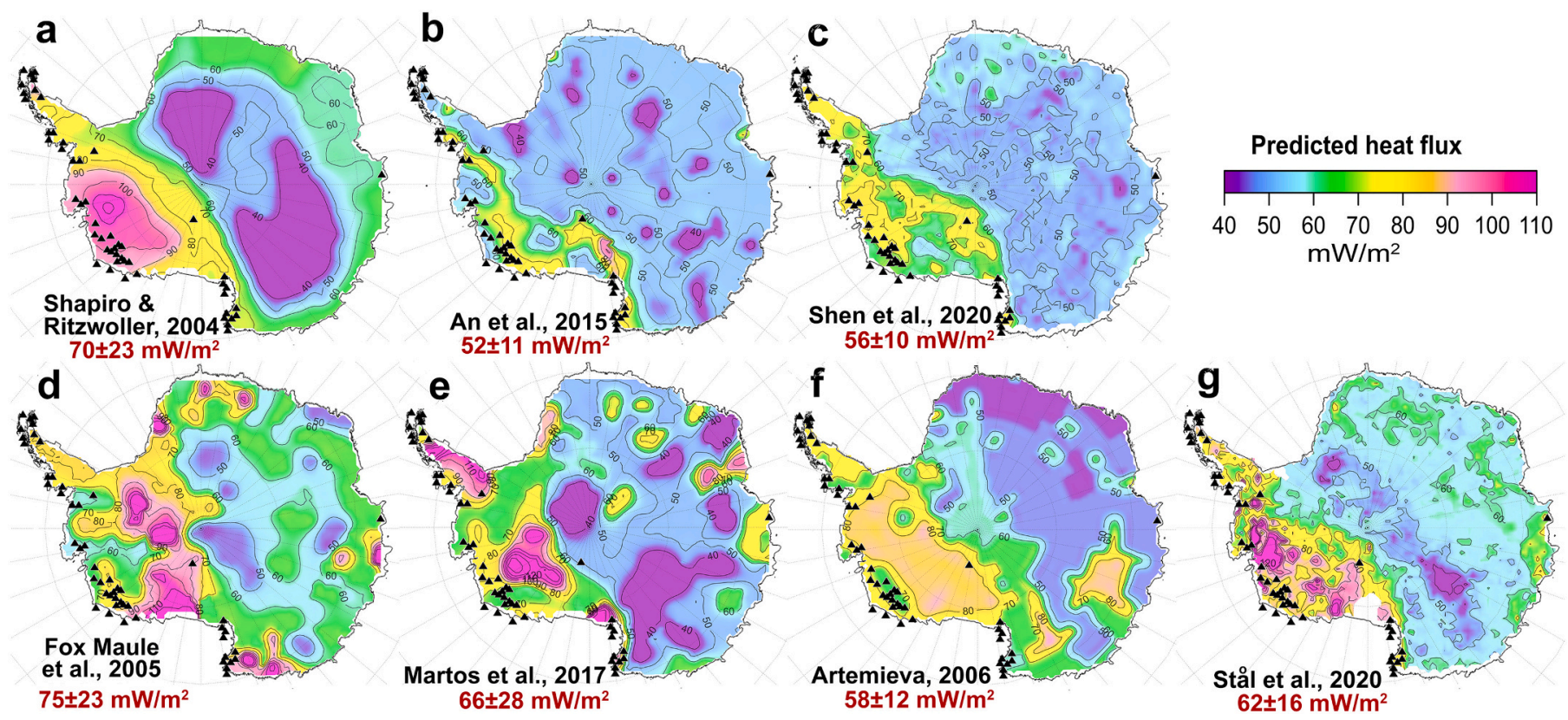

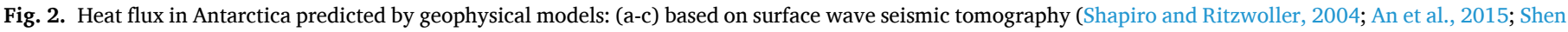

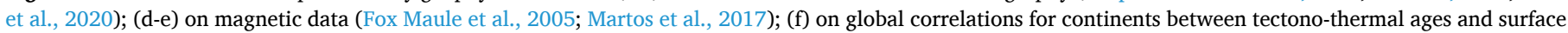

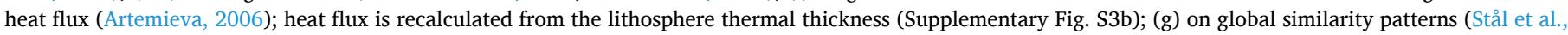

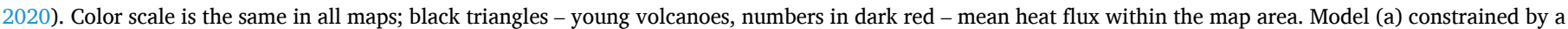

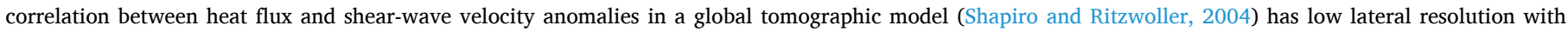

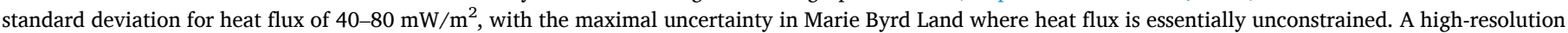

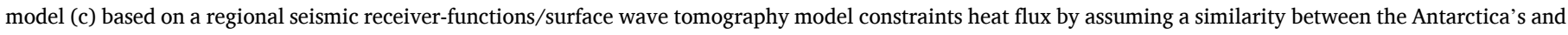

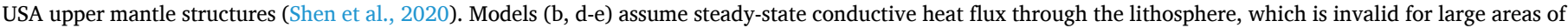

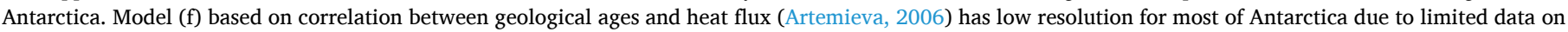

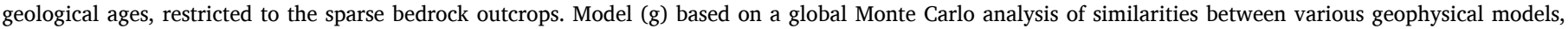

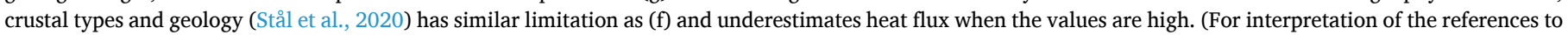
color in this figure legend, the reader is referred to the web version of this article.)

has low resolution for most of Antarctica (Fig. 2f) where geological ages are poorly known due to the sparse bedrock outcrops. A continent-scale heat flux model (Stål et al., 2020) based on a global cross-correlation analysis of gravity, magnetic, and seismic models (Fig. 2g) has similar limitations, since it combines geophysical data with poorly constrained regional geological models on crustal type and age, and the model (where poor correlation between many parameters is tuned by weighting factors) tends to underestimate heat flux in regions with very high values (Stål et al., 2020), such as reported in other geophysical models for West Antarctica.

\subsection{Local glaciological and borehole studies}

Due to the ice cover, conventional heat flux measurements in bedrock drill-holes are almost absent in Antarctica and, where exist, the critical mathematical assumption behind the method formulation (Pollack et al., 1993) - conductive steady-state heat transfer - is not satisfied. Advection, convection and water circulation may dominate heat transfer in conventional borehole measurements in the volcanic provinces of the Ross Sea (Morin et al., 2010) and in unconsolidated sediments of the Subglacial Lake Whillans in West Antarctica (Fisher et al., 2015), where the inferred extreme heat flux values of $164 \mathrm{~mW} / \mathrm{m}^{2}$ and $285 \pm 80 \mathrm{~mW} / \mathrm{m}^{2}$, respectively, are incompatible with the assumed steady-state lithosphere conduction.

Likewise, glaciological heat flux estimates, e.g. heat flux measurements in ice drill-holes (Table 1), suffer from large uncertainties due to many unknowns, such as ice-flow pattern (Robel et al., 2013), paleosurface temperatures, and paleo-accumulation rates of the ice (DahlJensen et al., 1998; Morin et al., 2010; Fisher et al., 2015; Hanna et al., 2020). Reliable calculations require measurements close to the ice bottom, where subglacial meltwater leaking into the borehole may significantly reduce inferred heat flux values, so that only a minimum heat flux value can be estimated. Accounting for a possible ice melting critically affects the estimated heat flux (Talalay et al., 2020), as illustrated by results at the Vostok Lake deep ice drill-hole in East Antarctica (Fig. 1), where the reported values (affected by meltwater) range from ca. $50 \mathrm{~mW} / \mathrm{m}^{2}$ (Salamatin et al., 1998) to a physically unrealistic negative value of geothermal heat flux when ice melting is included (Talalay et al., 2020), while an alternative approach based on the presence of thermophile bacteria in the meltwater yields ca. $220 \mathrm{~mW} /$ $\mathrm{m}^{2}$ (Bulat et al., 2012). Besides, most of glaciological heat flux studies in ice drill-holes (Talalay et al., 2020) adopt the approach developed for the tectonically stable Greenland craton (Dahl-Jensen et al., 1998), which assumes a steady-state lithosphere thermal regime, invalid for West Antarctica and parts of East Antarctica.

An alternative approach with radar-derived estimates is based on a strong amplitude increase of the reflected echoes in the presence of water. While the method assumes that water at the ice-rock interface is due to local ice basal melting (Fujita et al., 2012), it can originate from a meltwater flow from elsewhere (Le Brocq et al., 2013). Heat flux uncertainty based on ice borehole measurements can best be illustrated by the extraordinary difference of $180 \mathrm{~mW} / \mathrm{m}^{2}$ between the geothermal and basal ice heat fluxes measured in the same ice drill-hole (Lake Whillans, Fig. 1) in West Antarctica, with the difference attributed to a high-rate ( $18 \mathrm{~mm} / \mathrm{y}$ ) of ice basal melting (Fisher et al., 2015), while other explanations are possible. Likewise, airborne radar-derived study of heat flux beneath the Thwaites Glacier (West Antarctica, Fig. 1) (Schröeder et al., 2014) constrains a minimum average value of ca. 114 $\mathrm{mW} / \mathrm{m}^{2}$ with local anomalies exceeding $200 \mathrm{~mW} / \mathrm{m}^{2}$. This strong shortwavelength heterogeneity possibly reflects basal melting patterns and 
Table 1

Local heat flux studies in Antarctica.

\begin{tabular}{|c|c|c|c|c|}
\hline $\begin{array}{l}\text { Abbre- } \\
\text { viation }\end{array}$ & Location & $\begin{array}{l}\text { Heat flux, } \\
\mathrm{mW} / \mathrm{m}^{2}\end{array}$ & Method & Reference $^{2}$ \\
\hline WA & $\begin{array}{l}\text { West } \\
\text { Antarctica }\end{array}$ & $\begin{array}{l}\text { Regional } \\
\text { mean } 97 \pm \\
21\end{array}$ & Thermal isostasy & $\begin{array}{l}\text { This } \\
\text { study }\end{array}$ \\
\hline \multirow[t]{3}{*}{ LW } & Lake Whillans & $105 \pm 13$ & $\begin{array}{l}\text { Ice-hole down to } \\
\text { bedrock, T-log }\end{array}$ & F15 \\
\hline & & $285 \pm 80$ & Radar & F15 \\
\hline & $\begin{array}{l}\text { Whillans Ice } \\
\text { Stream }\end{array}$ & $88 \pm 7$ & $\begin{array}{l}\text { Subglacial sediment, } \\
\text { T-log }\end{array}$ & B17 \\
\hline RS & $\begin{array}{l}\text { Ross Sea } \\
\text { region }\end{array}$ & $60-115$ & $\begin{array}{l}\text { Boreholes in bedrock, } \\
\text { T-log }\end{array}$ & cf. M10 \\
\hline SD & Siple Dome & $69 \pm 1$ & $\begin{array}{l}\text { Ice-hole down to } \\
\text { bedrock, T-log }\end{array}$ & E04 \\
\hline TG & $\begin{array}{l}\text { Thwaites } \\
\text { Glacier }\end{array}$ & $114 \pm 10$ & $\begin{array}{l}\text { Radar, minimum } \\
\text { average }\end{array}$ & S14 \\
\hline WA & WAIS Divide & $215 \pm 14$ & $\begin{array}{l}\text { Ice-hole halted } 50 \mathrm{~m} \\
\text { above the bedrock, T- } \\
\log \end{array}$ & WAIS13 \\
\hline BY & Byrd drill-hole & 117 & $\begin{array}{l}\text { Ice-hole down to } \\
\text { bedrock, meltwater at } \\
\text { the base, T-log, } \\
\text { melting accounted for }\end{array}$ & $\mathrm{T} 20$ \\
\hline VL & Victoria Land & $100-120^{1}$ & Xenolith geotherm & AP10 \\
\hline EA & $\begin{array}{l}\text { East } \\
\text { Antarctica }\end{array}$ & $\begin{array}{l}\text { Regional } \\
\text { mean } 67 \pm \\
22\end{array}$ & Thermal isostasy & $\begin{array}{l}\text { This } \\
\text { study }\end{array}$ \\
\hline CL & $\begin{array}{l}\text { Concordia } \\
\text { Lake }\end{array}$ & $\sim 100$ & Radar & C09 \\
\hline CEA & $\begin{array}{l}\text { Central East } \\
\text { Antarctica }\end{array}$ & $33-84$ & $\begin{array}{l}\text { Based on heat } \\
\text { production in local } \\
\text { granites }\end{array}$ & G18 \\
\hline DC & Dome C & $55 \pm 4$ & Radar & P17 \\
\hline DF & Dome Fuji & 59 & $\begin{array}{l}\text { Ice-hole stopped } 590 \mathrm{~m} \\
\text { above bedrock, isotope } \\
\text { record calibrated by } \\
\text { Vostok data }\end{array}$ & H02 \\
\hline KO & $\begin{array}{l}\text { Kohnen drill- } \\
\text { hole }\end{array}$ & 55 & $\begin{array}{l}\text { Ice-hole down to } \\
\text { bedrock, meltwater at } \\
\text { the base, T-log }\end{array}$ & H07 \\
\hline LD & Law Dome & 75 & $\begin{array}{l}\text { Ice-hole down to } \\
\text { bedrock, T-log }\end{array}$ & DJ99 \\
\hline LV & Lake Vostok & $50-56$ & Ice core isotope record & S98 \\
\hline & & $220-240$ & Thermophile bacteria & B12 \\
\hline PB & Prydz Bay & $31-83$ & $\begin{array}{l}\text { Based on heat } \\
\text { production in local } \\
\text { granites }\end{array}$ & C14 \\
\hline SP & $\begin{array}{l}\text { South Pole } \\
\text { region }\end{array}$ & $120 \pm 20$ & Radar & $\mathrm{J} 18$ \\
\hline AP & $\begin{array}{l}\text { Antarctic } \\
\text { Peninsula tip, } \\
\text { James Ross } \\
\text { Island }\end{array}$ & $\sim 50$ & $\begin{array}{l}\text { Ice-hole down to } \\
\text { bedrock, T-log, heat } \\
\text { flux inferred from the } \\
\text { ice base temperature }\end{array}$ & M12 \\
\hline AP & $\begin{array}{l}\text { Antarctic } \\
\text { Peninsula, } \\
\text { central, } \\
\text { Graham Land }\end{array}$ & $\sim 100$ & $\begin{array}{l}\text { Ice-hole down to } \\
\text { bedrock, unaffected by } \\
\text { meltwater, T-log, heat } \\
\text { flux inferred from the } \\
\text { ice base temperature }\end{array}$ & NP93 \\
\hline AP & $\begin{array}{l}\text { Antarctic } \\
\text { Peninsula }\end{array}$ & $\begin{array}{l}\text { Mean } \\
70-80\end{array}$ & $\begin{array}{l}\text { Based on assumed heat } \\
\text { production in mapped } \\
\text { bedrock }\end{array}$ & BJ17 \\
\hline
\end{tabular}

${ }^{1}$ Not reported in the original publication; inferred from xenolith geotherm.

${ }^{2}$ References: $A P 10=$ Armienti and Perinelli, 2010; B12 = Bulat et al., 2012; $B 17=$ Begeman et al., 2017; BJ17 = Burton-Johnson et al., 2017; C09 = Carter et al., 2009; C14 = Carson et al., 2014; DJ99 = Dahl-Jensen et al., 1999; E04 = Engelhardt, 2004; F15 = Fisher et al., 2015; G18 = Goodge, 2018; H02 = Hondoh et al., 2002; HO7 = Huybrechts et al., 2007; J18 = Jordan et al., 2018; M10 = Morin et al., 2010; M12 = Mulvaney et al., 2012; NP93 = Nicholls and Paren, 1993; $P 17$ = Passalacqua et al., 2017; 1 14 = Schröeder et al., 2014; S98 = Salamatin et al., 1998; T20 = Talalay et al., 2020; WAIS13 = WAIS Divide Project Members, 2013 subglacial water routing.

This brief overview summarizes the problem: geothermal heat flux in Antarctica remains highly controversial (Fig. 2, Table 1 ) and it is poorly constrained despite strong multidisciplinary efforts by geophysical and glaciological communities, with a growing number of local (Salamatin et al., 1998; Morin et al., 2010; Bulat et al., 2012; Fujita et al., 2012; Fisher et al., 2015; Talalay et al., 2020), regional (Behrendt, 1999; Ferraccioli et al., 2011; Carson et al., 2014; Schröeder et al., 2014; Goodge, 2018), and continent-scale (Shapiro and Ritzwoller, 2004; Fox Maule et al., 2005; Artemieva, 2006; An et al., 2015; Martos et al., 2017; Haeger et al., 2019; Artemieva and Thybo, 2020; Lösing et al., 2020; Shen et al., 2020; Stål et al., 2020) studies.

\section{New Antarctica thermal model}

Here I present a new model for the thermal state of the Antarctic lithosphere based on the thermal isostasy method (Artemieva, 2019ab; Artemieva and Shulgin, 2019) (for details and uncertainty analysis see Methods and Supplementary Information). Therefore, the results are based on a new methodological approach, which has not been yet applied to Antarctica. Recent studies demonstrate that Antarctica's hypsometry cannot be explained by Airy-type crustal compensation neither for East (O'Donnell and Nyblade, 2014) nor for West Antarctica (Artemieva and Thybo, 2020). The thermal isostasy method separates crustal and mantle contributions to the isostasy, and uses the mantle component to determine lithosphere thermal thickness and geothermal heat flux in regions where the Moho depth is constrained by seismic methods (Supplementary Fig. S1). The method does not require the assumption of a steady-state lithosphere thermal regime, in contrast to other continent-scale models, and it was tested for Europe and the North Atlantics where the method predicts heat flux within a $<20 \mathrm{~mW} / \mathrm{m}^{2}$ range of high-quality borehole measurements (Artemieva, 2019a).

The new model for the lithosphere thermal thickness (Fig. 3) and geothermal heat flux (Fig. 4) deviate significantly from the previous Antarctica thermal models based on seismic tomography, magnetic data and global heat flux statistical correlations (Shapiro and Ritzwoller, 2004; Fox Maule et al., 2005; Artemieva, 2006; An et al., 2015; Martos et al., 2017; Haeger et al., 2019; Shen et al., 2020; Stål et al., 2020) (Fig. 2). It confirms the fundamental difference in gross lithosphere structure and thermal regime between East and West Antarctica. However, several previously unknown large-scale features of the lithosphere architecture, especially in the cratonic East Antarctica (Fig. 3), indicate that the conventional bi-modal view on the Antarctica's lithosphere is an oversimplification.

\subsection{East Antarctica}

East Antarctica is conventionally interpreted as a Precambrian shield formed by amalgamation of Archean to Mesoproterozoic lithosphere terranes. Based on geological similarity between bedrock outcrops in the coastal zone and the Kalahari, Dharwar, Yilgarn and Gawler cratons, the East Antarctica craton is interpreted as a part of Gondwanaland until its Mesozoic break-up (Dalziel, 1992). A very high topography of northern and central East Antarctica (the Gamburtsev Mountains, the Dronning Maud Land Mountains and the Vostok Highlands, Fig. 1), atypical of Precambrian shields, was interpreted as epeirogeny related to anomalies in the mid-to-lower mantle (O'Donnell and Nyblade, 2014). The present results indicate that East Antarctica topographic anomalies may be caused by upper mantle thermal heterogeneity.

The lithosphere of the East Antarctica craton has largely lost its cratonic signature (Fig. 3). Well resolved parts of East Antarctica (where seismic Moho is constrained by local data, rather than by interpolations over broad distances, Supplementary Figs. S1, S4) have a non-cratonic, high heat flux with several large-scale sub-glacial anomalies (Fig. 4) which may be crucial for ice-sheet dynamics but are absent in existing models (Fig. 2). The LAB (lithosphere-asthenosphere boundary) depth 


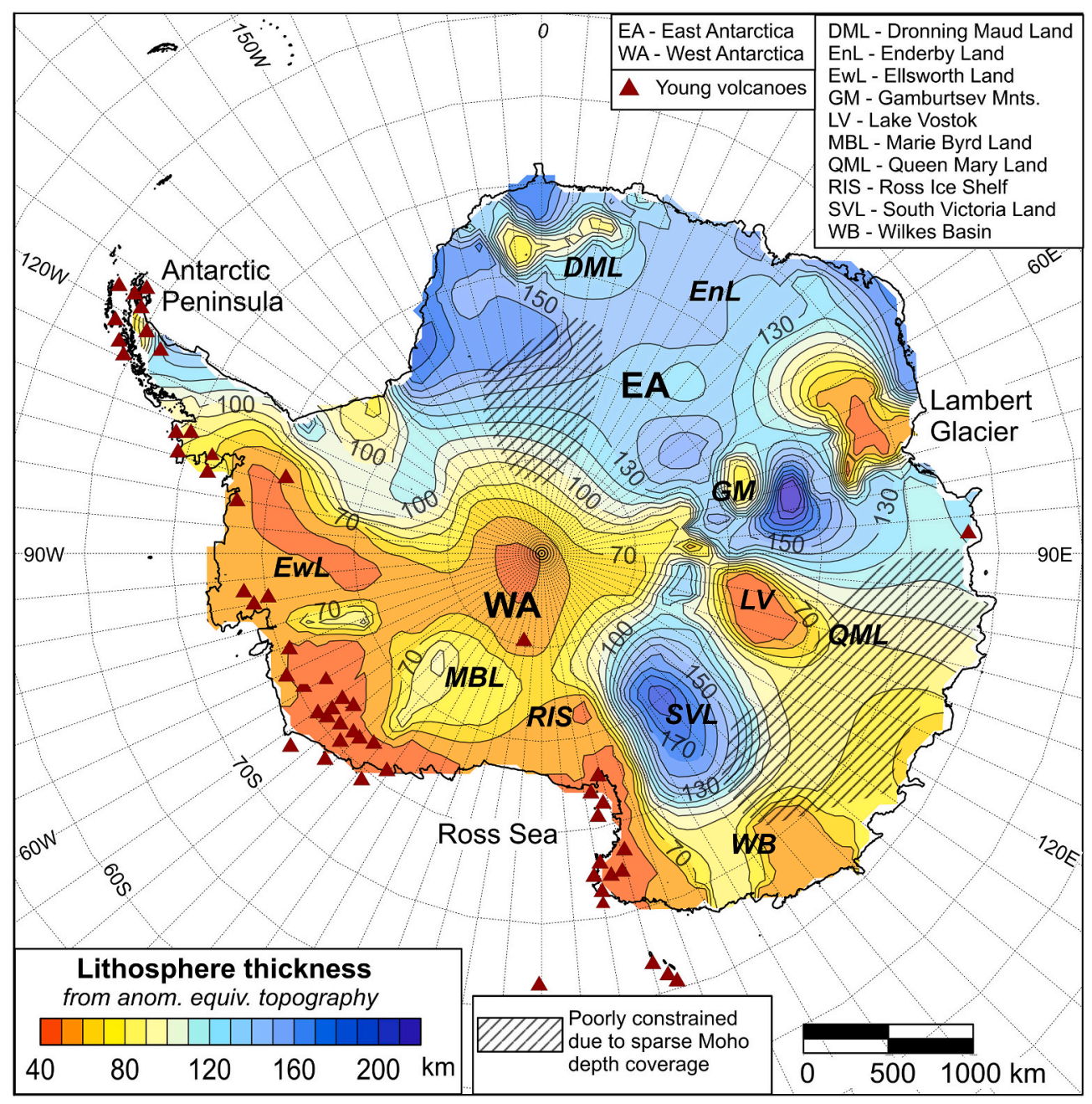

Fig. 3. Lithosphere thickness in Antarctica from thermal isostasy. See Methods for details.

typically at $130-150 \mathrm{~km}$ (Fig. 3) is significantly smaller than expected for preserved cratonic lithosphere (Pollack et al., 1993; Rudnick et al., 1998; Griffin et al., 1999; Shapiro and Ritzwoller, 2004; Artemieva, 2006; Shen et al., 2020; Stål et al., 2020). The deepest lithosphere root of $\sim 180-200 \mathrm{~km}$ is reached only locally near the Gamburtsev Mountains, where short-wavelength, high-amplitude variations in LAB depth (up to $80-100 \mathrm{~km}$ in depth over a distance of 500-800 km, Fig. 3) may, in part, be caused by lithosphere flexural deformation (Ferraccioli et al., 2011). Likewise, in most of the East Antarctica craton heat flux is higher than in cratons worldwide (Pollack et al., 1993; Rudnick et al., 1998; Artemieva, 2006), with typical values of $50-60 \mathrm{~mW} / \mathrm{m}^{2}$ and anomalously high heat flux of $100-120 \mathrm{~mW} / \mathrm{m}^{2}$ in several areas. In contrast, previous continent-scale geophysical models predict a nearly uniform heat flux in East Antarctica as expected for cratonic lithosphere (Fig. 2).

In Dronning Maud Land, the high topography region has a relatively thin lithosphere (80-100 km, Fig. 3) and high, non-cratonic heat flux values of $60-90 \mathrm{~mW} / \mathrm{m}^{2}$ (Fig. 4), so that the anomalous elevation is essentially supported by a mantle thermal anomaly. With a dense seismic data coverage on the Moho depth (Supplementary Fig. S1), the thermal model for this region is well constrained. However, the anomaly is not recognized in previous geophysical models, except for a satellitebased magnetic model (Fox Maule et al., 2005) (Fig. 2d), and a gravitybased conclusion on the mantle source for high elevation of the Dronning Maud Land Mountains (O'Donnell and Nyblade, 2014). The Kohnen ice drill-hole at the edge of the high heat flux anomaly allows for comparing geophysical and glaciological heat flux models (Fig. 4). The drill-hole measurements are affected by subglacial water and show a huge discrepancy between the values: $54.6 \mathrm{~mW} / \mathrm{m}^{2}$ and $161.5 \mathrm{~mW} / \mathrm{m}^{2}$ for models without (Talalay et al., 2020) and with basal melting (Huybrechts et al., 2007), respectively. The present result indicates that basal melting is important near the drill-hole, where the non-cratonic heat flux suggests possible presence of local, very high heat flux anomalies along major fault zones. Such local anomalies cannot be resolved in this study.

Anomalously thin lithosphere and a very high heat flux $(\sim 100 \mathrm{~mW} /$ $\mathrm{m}^{2}$ ) are characteristic for the Lambert Rift at the NE edge of the Gamburtsev Mountains. The rift is a part of the Gondwanan (Permian, reactivated in Cretaceous) intracontinental rift system that cuts through Australia's NW shelf and eastern India (Harrowfield et al., 2005), and the high heat flux anomaly can also be related to the Kerguelen hotspot. Lithosphere thinning to 50-70 km may have been enhanced by lithosphere deformation in the Gamburtsev Mountains, which provide the back-stop for rift propagation. With few exceptions (Martos et al., 2017) (Fig. 2e), this large-scale anomaly has not been recognized in previous continent-scale studies, while a very high heat flux may significantly enhance basal melting of the near-by, Antarctica's largest, Lambert Glacier, possibly facilitating its sliding to the ocean through sliding lubrication. Conventional borehole and ice drill-hole heat flux measurements are absent for the Lambert Rift, while a local thermal model for the Prydz Bay south of the Lambert Rift constrained by measurements of heat production in outcropping granites is consistent with the results of the present study (Carson et al., 2014) (Table 1, Fig. 4).

A major East Antarctica heat flux anomaly is inferred around Lake Vostok, where the lithosphere is thinned to $<70 \mathrm{~km}$ and heat flux 


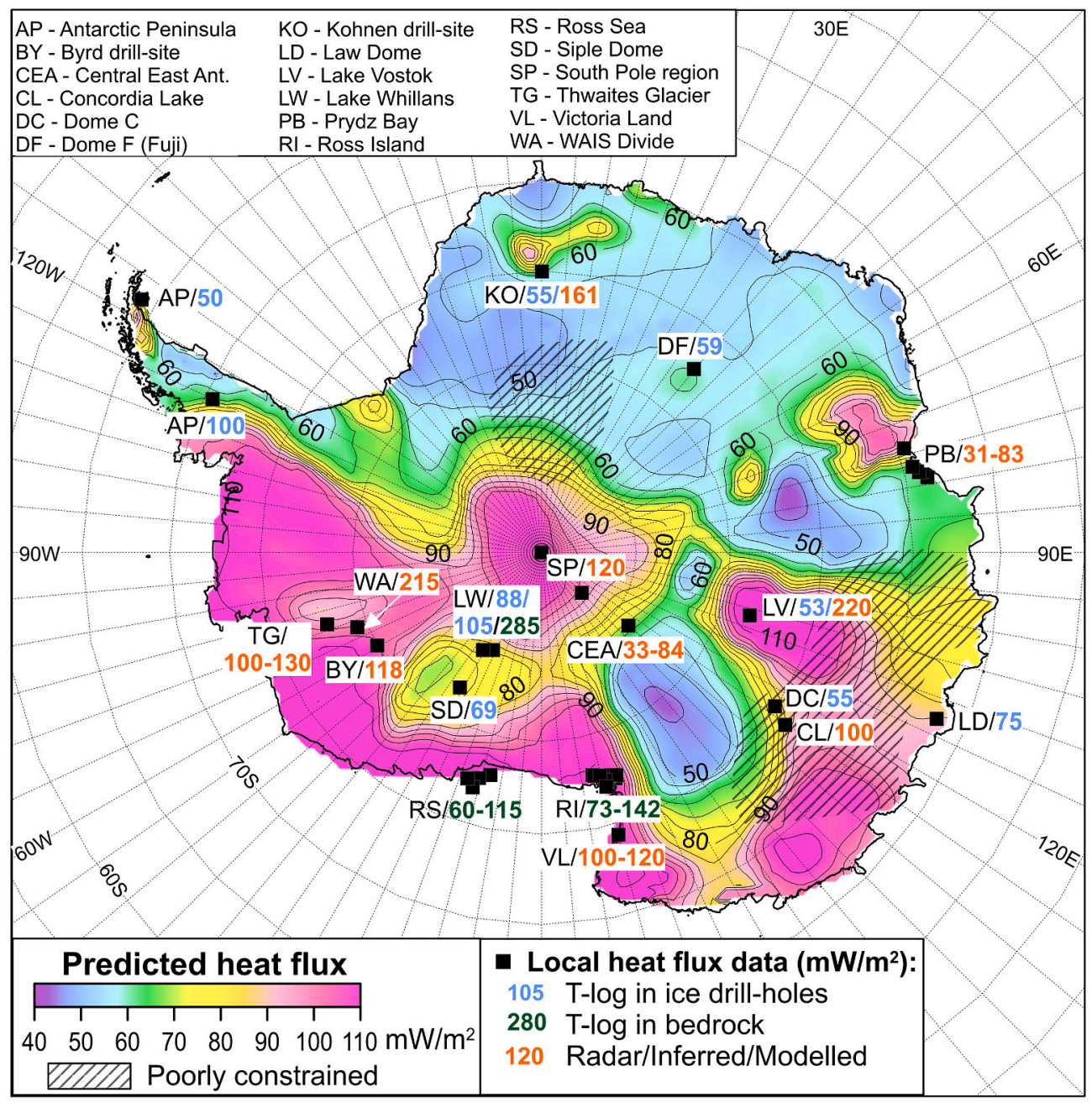

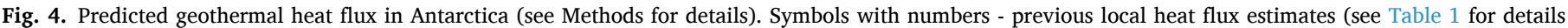
and references).

exceeds $120 \mathrm{~mW} / \mathrm{m}^{2}$ (Figs. 3, 4). The anomaly is constrained by a limited dataset (Supplementary Fig. S1) and its lateral extent is unknown due to poor seismic coverage for the Moho depth, which is based on interpolations in the eastern and southern directions from Lake Vostok (Supplementary Fig. S4). Based on a joint analysis of aeromagnetic, gravity and seismic receiver-function data, the Lake Vostok region was interpreted as a $400-\mathrm{km}$-wide, more than 10-km-deep sedimentary basin with the Moho at a ca. $30 \mathrm{~km}$ depth (Studinger et al., 2003). Compared to a typical cratonic crust with a ca. $40 \mathrm{~km}$ thick crystalline basement, the inferred crustal structure at the Lake Vostok region suggests a ca. $50 \%$ crustal thinning, consistent with the calculated strong lithosphere thinning (Fig. 3). The extremely high heat flux in the region (Fig. 4), which suggests possible magmatism below the lake, is in contrast to other (except for Artemieva (2006)) existing geophysical models which predict heat flux of $35-55 \mathrm{~mW} / \mathrm{m}^{2}$, typical of stable cratonic lithosphere (Fig. 2). While the cratonic heat flux of $50-56 \mathrm{~mW} / \mathrm{m}^{2}$ was also proposed based on the deuterium isotope record in the Vostok ice core (Salamatin et al., 1998), this result is questioned (Bulat et al., 2012; Jean-Baptiste et al., 2001). Although helium isotopes suggest no mantle signature in the accreted basal ice section (Studinger et al., 2003), the detection of thermophile bacterium near the base of the ice, which requires water temperatures as high as $50^{\circ} \mathrm{C}$, confirms the presence of a high heat flux anomaly with estimated values of up to $200-240 \mathrm{~mW} / \mathrm{m}^{2}$ (Bulat et al., 2012) and supports the results of the present study, which cannot constrain heat flux higher than $120 \mathrm{~mW} / \mathrm{m}^{2}$ (Supplementary Fig. S3b). Undoubtedly, magmatic activity below the lake bottom can explain such extreme heat flux values and can strongly enhance the ice-sheet melting.

The high heat flux Lake Vostok anomaly may be linked to the Wilkes Basin (Fig. 4) with a similar anomalous lithosphere structure (Artemieva and Thybo, 2020). The results are consistent with glaciological models which predict a heat flux of $\sim 80-105 \mathrm{~mW} / \mathrm{m}^{2}$ to explain the origin of sub-glacial lakes in the Terre Adélie and George V Land by local basal ice melting (Siegert and Dowdeswell, 1996). The South Victoria Land between the Trans-Antarctic Mountains and the Lake Vostok anomaly stands out as a preserved cratonic terrane with a LAB depth of $>150 \mathrm{~km}$ and heat flux $<50 \mathrm{~mW} / \mathrm{m}^{2}$ (Figs. 3, 4). Similar to the Lake Vostok anomaly, its lateral extent cannot be constrained by the existing data, and only the northern part of the terrane is well constrained by the modeling.

The large South Pole heat flux anomaly with estimated values of $>110 \mathrm{~mW} / \mathrm{m}^{2}$ (Fig. 4) is absent in all previous geophysical models for Antarctica heat flux (Fig. 2a-e), but is known locally from radar data which requires a geothermal flux of $120 \pm 20 \mathrm{~mW} / \mathrm{m}^{2}$ to explain the basal melting rate of up to $6 \pm 1 \mathrm{~mm} / \mathrm{y}$ around the South Pole (Jordan et al., 2018). This local radar study could not constrain the size of the anomaly, which apparently links to the West Antarctica high heat flux province.

\subsection{West Antarctica}

Tectonic terranes of West Antarctica include (Fig. 1): the Antarctic 
Peninsula continental volcanic arc formed along the Gondwanan margin and reactivated as a volcanic arc after the Gondwana break-up (BurtonJohnson et al., 2017), an outcropping Mesoproterozoic block between the Antarctic Peninsula and Ellsworth Land (Dalziel, 1992), the Ellsworth Mountains with a possible Precambrian basement, and a huge topographic depression which includes Ellsworth Land, Marie Byrd Land, and the Ross Ice Shelf. The area, recognized as one of the world's largest zones of episodic crustal extension (cf. Behrendt, 1999) with a broadly distributed Meso-Cenozoic magmatic activity, is interpreted either as the West Antarctica Rift System (cf. Behrendt, 1999), or as a system of back-arc basins formed along the paleo-Pacific active margin (Artemieva and Thybo, 2020). The origin of the Trans-Antarctic Mountains, the largest non-compressional belt of high topography that makes the tectonic boundary between East and West Antarctica, is debated, and existing models include combinations of thermally and/or mechanically driven uplift (van Wijk et al., 2008).

A fundamental difference between the present (Fig. 4) and previous Antarctica's heat flux models (Fig. 2) is that the locations of young volcanoes along the entire western margin of Antarctica correspond to areas with inferred very thin $(<50 \mathrm{~km})$ lithosphere and very high flux (100-120 mW/m $\mathrm{m}^{2}$ or higher) (Figs. 3-4). While a heat flux model based on similarity between the upper mantle thermal and velocity structures in Antarctica and USA (Fig. 2c) also has a belt of increased heat flux in the volcanic provinces (Shen et al., 2020), the maximum predicted values of $85 \mathrm{~mW} / \mathrm{m}^{2}$ are inconsistent with the very recent volcanic activity. Heat flux models based on magnetic data (Fox Maule et al., 2005; Martos et al., 2017) have the worst correlation with the young volcanic provinces (Fig. 2de), possibly because model assumptions on steadystate conductive heat flux are clearly invalid there.

The results show a principal difference between the gross lithosphere thermal structure of West and East Antarctica with mean heat flux of 97 $\pm 21 \mathrm{~mW} / \mathrm{m}^{2}$ and $67 \pm 22 \mathrm{~mW} / \mathrm{m}^{2}$, respectively, and corresponding mean lithosphere thicknesses of $70 \pm 38 \mathrm{~km}$ and $124 \pm 46 \mathrm{~km}$ (Supplementary Tables S1bc; regionalization used to calculate the regional averages is shown in Supplementary Fig. S4). Unlike East Antarctica, West Antarctica exhibits little heterogeneity in lithosphere thermal structure. Most of the area has an extremely thin lithosphere $(50-70 \mathrm{~km})$ with a high heat flux $\left(>100 \mathrm{~mW} / \mathrm{m}^{2}\right)$, as conventionally expected (Shapiro and Ritzwoller, 2004; Fox Maule et al., 2005; An et al., 2015; Martos et al., 2017; Haeger et al., 2019; Lösing et al., 2020; Shen et al., 2020). The major deviation from the regional pattern is in Marie Byrd Land, which preserves a terrane with a LAB depth of ca. $80 \mathrm{~km}$ and heat flux of $70-80 \mathrm{~mW} / \mathrm{m}^{2}$ typical of tectonically active Phanerozoic regions. A similar feature has been identified in several previous geophysical models, but at different locations (Fig. 2b-d). Extremely high heat flux values over all of West Antarctica, consistent with its back-arc geodynamic origin (Artemieva and Thybo, 2020), are in excellent agreement with local heat flux estimates based on radar and temperature measurements in ice drill-holes, subglacial sediments and bedrock boreholes (Fig. 4; Table 1).

\subsection{Trans-Antarctic Mountains}

The Trans-Antarctic Mountains are not resolved as a stand-alone lithosphere-scale anomaly (Figs. 3, 4). High heat flux $\left(>100 \mathrm{~mW} / \mathrm{m}^{2}\right)$ with a thin lithosphere are atypical of collisional orogens and support geological interpretations of non-orogenic origin. While the topographic escarpment along the western rim of the mountains suggests the presence of a major tectonic boundary, it is absent in the lithosphere structure. Instead, the eastern, cratonic rim of the mountains is marked by a sharp change in the lithosphere thickness. This pattern, consistent with edge-driven small-scale convection along cratonic margins (King and Anderson, 1998), supports models of thermo-mechanical uplift along the cratonic margin of East Antarctica (van Wijk et al., 2008).

\section{Geodynamic origin of large-scale lithosphere heterogeneity}

The new model for the thermal structure of the Antarctica lithosphere is consistent with the distribution of young volcanism, with local glaciological and local bedrock heat flux models, and is not based on the critical assumption of steady-state conduction assumed in most continent-scale models, despite being incorrect in many parts of the continent. The results identify several, previously unknown, large-scale lithosphere anomalies and allow for speculations on their geodynamic origin.

(1) Significant parts of the East Antarctica craton have lost the cratonic lithosphere signature.

(2) Lithosphere thinning below the Dronning Maud Land Mountains suggests a non-orogenic origin of the high topography.

(3) Extreme lithosphere thinning at the Lambert Rift is possibly caused by reactivation of a rheologically weak lithosphere of the Gondwanan rift by the Kerguelen hotspot.

(4) Extreme lithosphere thinning in the Lake Vostok region and the presence of a deep, wide sedimentary basin (Studinger et al., 2003) suggest strong lithosphere modification of the craton, such as associated with upper mantle thermo-mechanical instabilities (Fourel et al., 2013). Together with biogeochemical evidence for a high water temperature in the subglacial lake (Bulat et al., 2012), the results suggest magmatic activity below the ice-sheet, although the extent of the anomaly is unresolved.

(5) Thick lithosphere of South Victoria Land in East Antarctica may represent an unmodified Precambrian terrane, although its areal extent is unresolved.

(6) Thin lithosphere of the Trans-Antarctic Mountains, extending to the South Pole, supports a non-orogenic origin of the high topography and suggests that the mountain uplift is, at least in part, associated with mantle thermal instabilities and lithosphere flexure at the edge of the East Antarctica craton.

(7) Thin $(<50-70 \mathrm{~km})$ lithosphere of the entire West Antarctica is consistent with extreme extension, such as expected in back-arc basins (Artemieva and Thybo, 2020), and with young volcanism.

(8) A block with a 70-80 km thick, Phanerozoic-type continental lithosphere in Marie Byrd Land of West Antarctica may represent a separate terrane.

\section{Implications for deep-Earth and ice-sheet dynamics}

A fundamental new finding in the present model is a significantly higher mean flux in Antarctica $\left(81 \pm 26 \mathrm{~mW} / \mathrm{m}^{2}\right)$ than in all previous continent-scale models (Fig. 2, Supplementary Table S1). For West Antarctica, the modelled values are at least $10-30 \mathrm{~mW} / \mathrm{m}^{2}$ higher than predicted by most other geophysical models, despite the present modeling method cannot constrain heat flux values larger than 120 $\mathrm{mW} / \mathrm{m}^{2}$ (Supplementary Fig. S3b). All existing Antarctica-scale models significantly underestimate geothermal heat flux by $30-60 \mathrm{~mW} / \mathrm{m}^{2}$ in large regions of East Antarctica around the South Pole, Lake Vostok and the Lambert Rift. As a result, the present model provides average heat flux for the entire Antarctica which is $\sim 30 \%$ higher than the global continental average (Pollack et al., 1993), in part because large parts of West Antarctica may not be continental (this is indicated by the patterns of gravity anomalies and seismicity typical of back-arc systems, as well as by an anomalously deep bathymetry, an anomalously thin crust, and an anomalously low lithospheric density, not observed anywhere on continents (Artemieva and Thybo, 2020)). The estimated high heat flux values imply that meltwater production from the entire Antarctic icesheet may be up to $30 \%$ higher than the inferred value of $\sim 65 \mathrm{Gt} / \mathrm{y}$ based on the global continental average heat flux (Pattyn, 2010).

The identified heat flux anomalies, with possible magmatic activity 


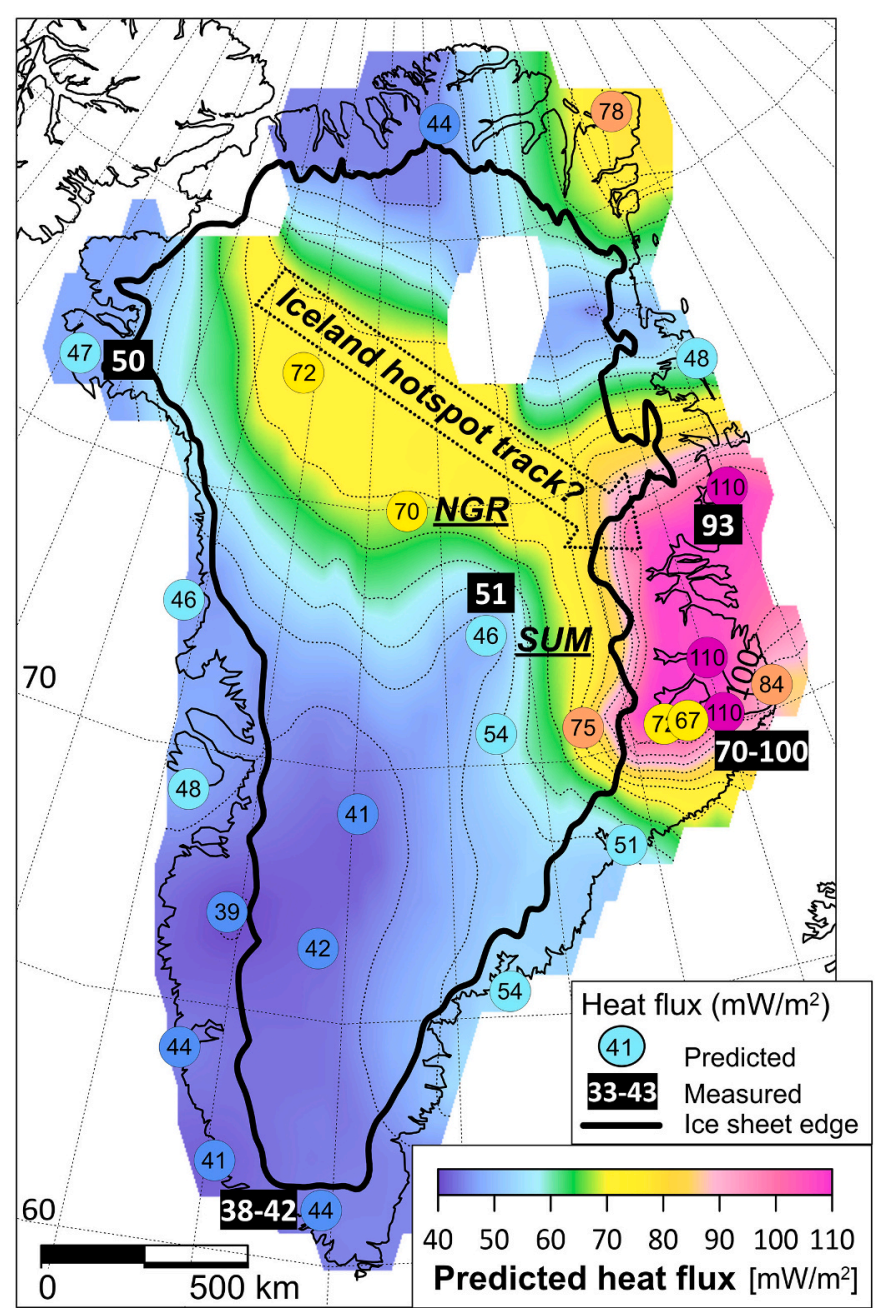

Fig. 5. Predicted geothermal heat flux in Greenland and local heat flux estimates (based on Artemieva, 2019b). Color code the same as in Fig. 4. Black line - outline of the ice sheet. In contrast to Antarctica, the area with the anomalously high heat flux is in the ice-free coastal zone.

below the ice-sheet, should have strong implications for the ice basal conditions. The results provide strong constrains on the source of meltwater in ice streams and the production rate. Basal melting controls ice stability and may lead to fast melt-water sliding of the ice-sheet into the ocean (Blankenship et al., 1993; MacAyeal, 1992; Marcott et al., 2011). It opens the possibility of a dramatically fast recycling of huge ice volumes (Heinrich, 1988) which may have critical consequences for sea level changes (Mitrovica et al., 2009) and ocean currents through changes in water salinity (Golledge et al., 2019). The results indicate that presently major planetary challenge does not originate from the Greenland ice-sheet, where a high heat flux anomaly is local and is located mostly beneath the ice-free coastal zone (Artemieva, 2019b) (Fig. 5), but from Antarctica where at least $1 / 3$ of the ice-sheet may be subject to intensive basal melting and at rates significantly higher than the existing ice dynamics models consider.

\section{Data and materials availability}

All data used in the paper are published in the cited references.

\section{Declaration of Competing Interest}

The author has no competing interests.

\section{Acknowledgements}

This work was supported by the grant 92055210 from National Science Foundation of China, the Royal Danish Academy of Sciences and Letters (det Kongelige Danske Videnskabernes Selskab), the Inge Lehmann grant (2019-2021) and partially supported through the MOST Special Funds for GPMR State Key Laboratory (CUG-Wuhan) (GPMR2019010). Minor suggestions of two anonymous reviewers are acknowledged.

\section{Appendix A. Methods}

The results are based on the thermal isostasy method (Artemieva, 2019a, 2019b; Artemieva and Shulgin, 2019), where it has been described in detail, including the uncertainty analysis, and used to constrain geothermal heat flux in several continental and oceanic regions. The method was tested in continental and off-shore Europe with dense coverage by high quality heat flow measurements where it predicts heat flux values in agreement with conventional borehole data, within a $<20 \mathrm{~mW} / \mathrm{m}^{2}$ range of high-quality borehole measurements in regions with a well-constrained seismic Moho depth (Artemieva, 2019a).

Input parameters. The thermal isostasy method constrains regional geotherms and heat flux based on two parameters only: Moho depth and hypsometry, and therefore it is well suited for regions with sparse geophysical and geological data, like ice-covered Greenland (Artemieva, 2019b) and Antarctica. In this study, hypsometry is replaced by equivalent topography, since substantial parts of Antarctica are submerged below sea level and/or are covered by the ice-sheet. The ETOPO1 global hypsometry model is converted to equivalent topography by reducing thicknesses of ice (Fretwell et al., 2013) and water with densities of 920 $\mathrm{kg} / \mathrm{m}^{3}$ and $1020 \mathrm{~kg} / \mathrm{m}^{3}$, respectively, to bedrock density of $2670 \mathrm{~kg} / \mathrm{m}^{3}$. Equivalent topography (Fig. 1) is positive in most of East Antarctica with $0-1 \mathrm{~km}$ in most of the region and increasing to ca. $2-3.5 \mathrm{~km}$ at the Gamburtsev Mountains and Dronning Maud Land. West Antarctica is dominated by negative equivalent topography, $-580 \mathrm{~m}$ on average with local depressions down to $-1.6 \mathrm{~km}$ (Artemieva and Thybo, 2020). The Moho depth, constrained by seismic reflection/refraction profiles, seismic receiver functions, and surface wave tomography compiled from various sources (cf. Artemieva and Thybo, 2020), has typical continental values of 35-45 km in East Antarctica, increasing to 50-58 km below the Gamburtsev Mountains, and anomalously thin crust $(20-30 \mathrm{~km})$ in substantial parts of West Antarctica (Supplementary Fig. S1).

Method in brief. The method assumes regional isostasy with isostatic compensation at the base of thermal lithosphere (LAB); this assumption is satisfied for most of Antarctica, which is close to isostatic equilibrium with near-zero free air gravity anomalies (Artemieva and Thybo, 2020). The validity of other model assumptions is discussed below. Local deviations of equivalent topography from isostatic predictions (termed anomalous equivalent topography, Supplementary Fig. S2) are assumed to be caused by thermal anomalies in the lithosphere. These, in turn, depend on the lithosphere thermal thickness and geothermal heat flux. The equations linking the anomalous equivalent topography to variations in lithosphere thermal thickness, lithospheric temperature variations, and geothermal heat flux are derived in (Artemieva, 2019a, 2019b) and are presented here graphically (Supplementary Fig. S3). Therefore, the method allows for assessing the lithosphere thermal thickness and geothermal heat flux in regions where the Moho depth is constrained by seismic methods (cf. Artemieva and Thybo, 2020).

Regional isostasy. The assumption of regional isostasy is supported by near-zero $(-20$ to $+20 \mathrm{mGal})$ free-air anomalies over most of Antarctica (Supplementary Fig. S1). Weakly positive anomalies $(+50+70 \mathrm{mGal})$ at the Gamburtsev Mountains and weakly negative anomalies (around -50 $\mathrm{mGal}$ ) at Southern Victoria Land indicate some deviation from the isostatic equilibrium, possibly caused by lithosphere flexure (van Wijk et al., 2008; Ferraccioli et al., 2011). This effect cannot be accounted for 
by the method (Artemieva, 2019a), but it is expected to be small due to small gravity anomalies.

Isostatic compensation is achieved at the lithosphere base (LAB), so that isostatic variations in equivalent topography are caused by variations in the thickness and density of both the crust and the lithospheric mantle. Crustal thickness in Antarctica is known from seismic models (cf. Artemieva and Thybo, 2020), and densities of the crust and the lithospheric mantle are both affected by temperatures and composition. Crustal density heterogeneity (including both thermal and compositional components) is compensated by the Moho depth versus topography variations in Airy-type crustal isostasy. The first step is the calculation of the anomalous equivalent topography, AET (Supplementary Fig. S2), which is the deviation of the equivalent topography from the crustal isostasy predictions for a global continental crustal model with an average in situ crustal density of $2800 \mathrm{~kg} / \mathrm{m}^{3}$ atop the lithospheric mantle with in situ density of $3260 \mathrm{~kg} / \mathrm{m}^{3}$, which corresponds to SPT (standard, $P=1 \mathrm{~atm}, T=20^{\circ} \mathrm{C}$ ) densities of 2830 and $3370 \mathrm{~kg} / \mathrm{m}^{3}$, respectively. Density value for the mantle corresponds to fertile composition (Griffin et al., 1999). For other choices of the density values, see the sensitivity analysis below.

Lithosphere geotherms. The AET variations are caused by density anomalies in the lithospheric mantle of thermal and/or compositional origin. In case the AET is caused only by temperature anomalies (due to density heterogeneity caused by thermal expansion with the coefficient of $3.5 \times 10^{-5} 1 / \mathrm{K}$ ), these temperature anomalies can be calculated with respect to a reference location, where AET $=0 \mathrm{~km}$. Lithosphere geotherms control lithosphere thermal thickness (the LAB depth). Therefore, the AET anomalies are also directly related to lithosphere thermal thickness (Supplementary Fig. S3a) and can be converted to the LAB depth, if the lithosphere thickness is known from independent data at a location where AET $=0 \mathrm{~km}$. As a reference location I chose the area at ca. $170{ }^{\circ} \mathrm{W}, 73^{\circ} \mathrm{S}$ in Dronning Maud Land in East Antarctica (Supplementary Fig. S2) with a good coverage by seismic profiles and reliable constraints on the Moho depth. For this location I adopt a lithosphere thickness of $150 \mathrm{~km}$ based on seismic tomography models (Shapiro and Ritzwoller, 2004; An et al., 2015). Due to a strongly nonlinear relation between the AET and the lithosphere thickness (Supplementary Fig. S3a), a change in the reference lithosphere thickness will systematically shift the results without principal changes of the pattern (see below and Supplementary Fig. S5). Neglecting the compositional density heterogeneity of the lithospheric mantle is justified by its small variation $\left(<30 \mathrm{~kg} / \mathrm{m}^{3}\right)$ at $100 \mathrm{~km}$ depth in most of Antarctica (Haeger et al., 2019). Sensitivity analysis (Artemieva, 2019a) demonstrates that this variation has little effect on the calculated lithosphere temperature anomalies and therefore on the modelled heat flux values (see below and Supplementary Fig. S7).

Heat flux. Lithosphere geotherms are controlled by geothermal heat flux and heat production (Rudnick et al., 1998; Artemieva and Mooney, 2001; Mareschal and Jaupart, 2013). Global and regional studies (Pollack et al., 1993; Rudnick et al., 1998; Artemieva and Mooney, 2001; Artemieva, 2006; Mareschal and Jaupart, 2013) demonstrate that reference continental geotherms based on simple global assumptions on crustal heat production (Pollack et al., 1993; Rudnick et al., 1998) provide reliable constraints for continental lithosphere through correlation between heat flux and geotherms (Supplementary Fig. S3b). Strong local anomalies in heat production are reflected in heat flux anomalies through a linear relationship between the two parameters as observed in numerous regional studies worldwide (cf. Artemieva and Mooney, 2001; Mareschal and Jaupart, 2013); these crustal heat production anomalies contribute to local crustal isostasy, and are therefore reflected in the AET anomalies (Supplementary Fig. S2). Therefore, anomalies in crustal heat production are essentially accounted for by the method. The method cannot resolve a LAB depth less than $50 \mathrm{~km}$; therefore the maximum predicted heat flux is limited to $120 \mathrm{~mW} / \mathrm{m}^{2}$ (Fig. S3b), typical of continental regions with a highly extended, very thin lithosphere (Pollack et al., 1993; Artemieva, 2006). Consequently, the results underestimate heat flux in regions of young tectonomagmatic activity, such as in parts of West Antarctica (Blankenship et al., 1993; Behrendt, 1999; Artemieva and Thybo, 2020).

Model resolution. Lateral resolution of the model depends on the coverage by seismic data on the Moho depth (Supplementary Fig. S1). Data coverage is poor for the inner northern and eastern parts of East Antarctica. However, in many places the seismic station distance is very large, and several isolated seismic stations constrain "bull's eye" anomalies with an unknown areal extent. Many seismic stations are located on local topographic ice-free highs; to avoid bias of local topography variations on the modeling results, the Moho depth and the equivalent topography are averaged over a radius of $50 \mathrm{~km}$ around the stations. The maps are produced by kriging interpolation of all data, smoothed by Gaussian filtering.

Model uncertainty. Uncertainty of the modelled LAB depth and predicted heat flux depends on uncertainty of the seismic Moho depth and the assumptions on the LAB depth at a reference location, and average in situ densities of the crust and the lithospheric mantle. Uncertainty analysis is presented in detail in Supplementary Material (Supplementary Figs. S5-S7 and Supplementary Tables S1abc). For the choice of parameters specified above (reference LAB (for AET $=0 \mathrm{~km}$ ) at $150 \mathrm{~km}$ depth and in situ densities of $2800 \mathrm{~kg} / \mathrm{m}^{3}$ and $3260 \mathrm{~kg} / \mathrm{m}^{3}$ for the crust and the lithospheric mantle), the modelled Antarctica-averaged values are $98 \pm 50 \mathrm{~km}$ for LAB depth and $81 \pm 26 \mathrm{~mW} / \mathrm{m}^{2}$ for heat flux.

Changes in the Moho depth and reference $L A B$ depth values preserve the general pattern of the calculated LAB depth and heat flux anomalies and produce a systematic shift in the modeling results (Supplementary Fig. S5). If the Moho depth is $2 \mathrm{~km}$ deeper, the modelled average values are $110 \pm 54 \mathrm{~km}$ and $75 \pm 26 \mathrm{~mW} / \mathrm{m}^{2}$, that is $12 \%$ higher for the LAB depth and $7 \%$ lower for the predicted heat flux. For the LAB depth of $200 \mathrm{~km}$ at a reference location with AET $=0 \mathrm{~km}$, the modelled average values are $130 \pm 70 \mathrm{~km}$ and $72 \pm 30 \mathrm{~mW} / \mathrm{m}^{2}$, that is $33 \%$ higher for the $\mathrm{LAB}$ depth and $11 \%$ lower for the predicted heat flux (Supplementary Fig. S5). Separate analysis for East and West Antarctica (see Supplementary Fig. S4 for the adopted regionalization) is given in Supplementary Table S1.

Changes in crustal and mantle densities slightly affect the general pattern of the calculated LAB depth and heat flux anomalies (Supplementary Figs. S6-7). If in situ crustal density is increased to $2850 \mathrm{~kg} / \mathrm{m}^{3}$ (an oceanic-type crust with SPT density of $2900 \mathrm{~kg} / \mathrm{m}^{3}$ ) or mantle density is reduced to $3230 \mathrm{~kg} / \mathrm{m}^{3}$ (a strongly depleted cratonic lithospheric mantle with SPT density of $3325 \mathrm{~kg} / \mathrm{m}^{3}$ ), while keeping other parameters unchanged, the average calculated values for Antarctica do not change, while local values change by $-18 /+21 \mathrm{~km}$ for the LAB depth (deeper LAB in West Antarctica and shallower in East Antarctica) and $-7 /+14 \mathrm{~mW} / \mathrm{m}^{2}$ for heat flux (smaller in West Antarctica and higher in East Antarctica). The largest changes are for local anomalies at the Gamburtsev Mountains (around $80^{\circ} \mathrm{E}, 80^{\circ} \mathrm{S}$ ) and in Marie Byrd Land (around $10-40{ }^{\circ} \mathrm{W}, 82-85^{\circ} \mathrm{S}$ ). Note that the sensitivity test for various values of the lithospheric mantle density (Supplementary Table S1, Supplementary Fig. S7) provides a test for the effect of compositional heterogeneity of the lithospheric mantle on the modeling results, since the calculations are presented for two end-member scenarios of mantle composition: fertile mantle typical of Phanerozoic terranes and highly depleted mantle typical of Archean cratons (Griffin et al., 1999).

\section{Appendix B. Supplementary data}

Supplementary data to this article can be found online at https://doi. org/10.1016/j.earscirev.2022.103954.

\section{References}

An, M., Wiens, D.A., Zhao, Y., et al., 2015. Temperature, lithosphere-asthenosphere boundary, and heat flux beneath the Antarctic Plate inferred from seismic velocities. J. Geophys. Res. 120B, 8720-8742. 
Armienti, P., Perinelli, C., 2010. Cenozoic thermal evolution of lithospheric mantle in northern Victoria Land (Antarctica): evidences from mantle xenoliths. Tectonophysics 486, 28-35.

Artemieva, I.M., 2006. Global $1^{\circ} \times 1^{\circ}$ thermal model TC1 for the continental lithosphere: implications for lithosphere secular evolution. Tectonophysics 416, 245-277.

Artemieva, I.M., 2019a. Lithosphere structure in Europe from thermal isostasy. Earth-Sci. Rev. 188, 454-468.

Artemieva, I.M., 2019b. Lithosphere thermal thickness and geothermal heat flux in Greenland from a new thermal isostasy method. Earth-Sci. Rev, 188, 469-481.

Artemieva, I.M., Mooney, W.D., 2001. Thermal thickness and evolution of Precambrian lithosphere: a global study. J. Geophys. Res. 106B, 16,387-16,414.

Artemieva, I.M., Shulgin, A., 2019. Geodynamics of Anatolia: lithosphere thermal structure and thickness. Tectonics 38, 4465-4487.

Artemieva, I.M., Thybo, H., 2020. Continent size revisited: geophysical evidence for Wes Antarctica as a back-arc system. Earth-Sci. Rev. 202, 103106.

Begeman, C.B., Tulaczyk, S.M., Fisher, A.T., 2017. Spatially variable geothermal heat flux in West Antarctica: evidence and implications. Geophys. Res. Lett. 44, 9823-9832.

Behrendt, J.C., 1999. Crustal and lithospheric structure of the West Antarctic Rift System from geophysical investigations - a review. Glob. Planet. Change 23, 25-44.

Blankenship, D.D., Bell, R.E., Hodge, S.M., et al., 1993. Active volcanism beneath the West Antarctic ice sheet and implications for ice-sheet stability. Nature 361, 526-529.

Blunier, T., Brook, E.J., 2001. Timing of millennial-scale climate change in Antarctica and Greenland during the last Glacial Period. Science 291, 109-112.

Bond, G.C., Lotti, R., 1995. Iceberg discharges into the North Atlantic on millennial time scales during the last glaciation. Science 267, 1005-1010.

Bond, G., Heinrich, H., Broecker, W., et al., 1992. Evidence for massive discharges of icebergs into the North Atlantic ocean during the last glacial period. Nature 360, 245-249.

Broecker, W.S., 2002. Massive iceberg discharges as triggers for global climate change. Nature 372, 421-424.

Bulat, S.A., Marie, D., Petit, J.-R., 2012. Prospects for life in the subglacial Lake Vostok. Ice Snow 4, 92-96.

Burton-Johnson, A., Halpin, J.A., Whittaker, J.M., et al., 2017. A new heat flux model fo the Antarctic Peninsula incorporating spatially variable upper crustal radiogenic heat production. Geophys. Res. Lett. 44, 5436-5446.

Carson, C.J., McLaren, S., Roberts, J.L., et al., 2014. Hot rocks in a cold place: high sub glacial heat flow in East Antarctica. J. Geol. Soc. 171, 9-12.

Carter, S.P., Blankenship, D.D., Young, D.A., Holt, J.W., 2009. Using radar-sounding data to identify the distribution and sources of subglacial water: application to Dome C, East Antarctica. J. Glaciol. 55, 1025-1040.

Chulick, G.S., Mooney, W.D., 2002. Seismic structure of the crust and uppermost mantle of North America and adjacent oceanic basins: a synthesis. Bull. Seismol. Soc. Am. 92, 2478-2492.

Dahl-Jensen, D., Mosegaard, K., Gundestrup, N., et al., 1998. Past temperatures directly from the Greenland ice sheet. Science 282, 268-271.

Dahl-Jensen, D., Morgan, V.I., Elcheikh, A., 1999. Monte Carlo inverse modelling of the Law Dome (Antarctica) temperature profile. Ann. Glaciol. 29, 145-150.

Dalziel, I.W.D., 1992. Antarctica: a tale of two supercontinents? Annu. Rev. Earth Planet Sci. 20, 501-526.

DeConto, R.M., Pollard, D., 2016. Contribution of Antarctica to past and future sea-leve rise. Nature 531, 591-597.

Engelhardt, H., 2004. Ice temperature and high geothermal flux at Siple Dome, West Antarctica, from borehole measurements. J. Glaciol. 50, 251-256.

Ferraccioli, F., Finn, C.A., Jordan, T.A., et al., 2011. East Antarctic rifting triggers uplif of the Gamburtsev Mountains. Nature 479, 388-392.

Fisher, A.T., Mankoff, K.D., Tulaczyk, S.M., et al., 2015. High geothermal heat flux measured below the West Antarctic Ice Sheet. Sci. Adv. 1, e1500093.

Fourel, L., Milelli, L., Jaupart, C., Limare, A., 2013. Generation of continental rifts, basins, and swells by lithosphere instabilities. J. Geophys. Res. 118B, 3080-3100.

Fox Maule, C., Purucker, M.E., Olsen, N., Mosegaard, K., 2005. Heat flux anomalies in Antarctica revealed by satellite magnetic data. Science 309, 464-467.

Fretwell, P., et al., 2013. Bedmap2: improved ice bed, surface and thickness datasets for Antarctica. Cryosphere 7, 375-393.

Fujita, S., Holmlund, P., Matsuoka, K., et al., 2012. Radar diagnosis of the subglacial conditions in Dronning Maud Land, East Antarctica. Cryosphere 6, 1203-1219.

Golledge, N.R., Keller, E.D., Gomez, N., et al., 2019. Global environmental consequences of twenty-first-century ice-sheet melt. Nature 566, 65-72.

Goodge, J.W., 2018. Crustal heat production and estimate of terrestrial heat flow in central East Antarctica, with implications for thermal input to the East Antarctic ice sheet. Cryosphere 12, 491-504.

Griffin, W.L., O’Reilly, S.Y., Ryan, C.G., 1999. The composition and origin of subcontinental lithospheric mantle. Geochem. Soc. Spec. Publ. 6, 13-45.

Haeger, C., Kaban, M.K., Tesauro, M., Petrunin, A.G., Mooney, W.D., 2019. 3-D density, thermal, and compositional model of the Antarctic lithosphere and implications for its evolution. Geochem. Geophys. Geosyst. 20, 2018 GC008033.

Hanna, E., Pattyn, F., Navarro, F., et al., 2020. Mass balance of the ice sheets and glaciers progress since AR5 and challenges. Earth-Sci. Rev. 201, 102976.

Harrowfield, M., Holdgate, G.R., Wilson, C.J.L., McLoughlin, S., 2005. Tectonic significance of the Lambert Graben, East Antarctica: reconstructing the Gondwanan Rift. Geology 33, 197-200.
Heinrich, H., 1988. Origin and consequences of cyclic ice rafting in the Northeast Atlantic Ocean during the past 130,000 years. Quat. Res. 29, 142-152.

Hemming, S.R., 2004. Heinrich events: massive late Pleistocene detritus layers of the North Atlantic and their global climate imprint. Rev. Geophys. 42, RG1005.

Hondoh, T., Shoji, H., Watanabe, O., et al., 2002. Depth-age and temperature prediction at dome Fuji station, East Antarctica. Ann. Glaciol. 35, 384-390.

Huybrechts, P., Rybak, O., Pattyn, F., Ruth, U., Steinhage, D., 2007. Ice thinning, upstream advection, and non-climatic biases for the upper 89\% of the EDML ice core from a nested model of the Antarctic ice sheet. Clim. Past 3, 577-589.

Jean-Baptiste, P., Petit, J.R., Lipenkov, et al., 2001. Constraints on hydrothermal processes and water exchange in Lake Vostok from helium isotopes. Nature 411, 460-462.

Jordan, T.A., Martin, C., Ferraccioli, F., et al., 2018. Anomalously high geothermal flux near the South Pole. Sci. Rep. 8, 16785.

King, S.D., Anderson, D.L., 1998. Edge-driven convection. Earth Planet. Sci. Lett. 160, 289-296.

Le Brocq, A.M., Ross, N., Griggs, J.A., et al., 2013. Evidence from ice shelves for channelized meltwater flow beneath the Antarctic Ice Sheet. Nat. Geosci. 6, 945-948.

Li, C.-F., Lu, Y., Wang, J., 2017. A global reference model of Curie point depths based on EMAG2. Sci. Rep. 7, 45129.

Lösing, M., Ebbing, J., Szwillus, W., 2020. Geothermal Heat Flux in Antarctica: assessing Models and Observations by Bayesian Inversion. Front. Earth Sci. 8, 105.

MacAyeal, D., 1992. Irregular oscillations of the West Antarctic ice sheet. Nature 359, 29-32.

Marcott, S.A., Clark, P.U., Padman, L., et al., 2011. Ice-shelf collapse from subsurface warming as a trigger for Heinrich events. Proc. Natl. Acad. Sci. 108, 13415-13419.

Mareschal, J.-C., Jaupart, C., 2013. Radiogenic heat production, thermal regime and evolution of continental crust. Tectonophysics 609, 524-534.

Martos, Y.M., Catalán, M., Jordan, T.A., et al., 2017. Heat flux distribution of Antarctica unveiled. Geophys. Res. Lett. 44, 11,417-11,426.

Maslin, M., Seidov, D., Lowe, J., 2001. Synthesis of the nature and causes of rapid climate transitions during the Quaternary (PDF). AGU Geophys. Monogr. Series 126, 9-52.

Mitrovica, J.X., Gomez, N., Clark, P.U., 2009. The sea-level fingerprint of West Antarctic collapse. Science 323, 753.

Morin, R.H., Williams, T., Henrys, S.A., et al., 2010. Heat flow and hydrologic characteristics at the AND-1B borehole, ANDRILL McMurdo Ice Shelf Project, Antarctica. Geosphere 6, 370-378.

Mulvaney, R., Abram, N.J., Hindmarsh, R.C., et al., 2012. Recent Antarctic Peninsula warming relative to Holocene climate and ice-shelf history. Nature 489, 141-144.

Nicholls, K.W., Paren, J.G., 1993. Extending the Antarctic meteorological record using ice-sheet temperature profiles. J. Clim. 6, 141-150.

O'Donnell, J.P., Nyblade, A.A., 2014. Antarctica's hypsometry and crustal thickness: implications for the origin of anomalous topography in East Antarctic. Earth Planet. Sci. Lett. 388, 143-155.

Passalacqua, O., Ritz, C., Parrenin, F., et al., 2017. Geothermal flux and basal melt rate in the Dome $\mathrm{C}$ region inferred from radar reflectivity and heat modelling. Cryosphere $11,2231-2246$.

Pattyn, F., 2010. Antarctic subglacial conditions inferred from a hybrid ice sheet/ice stream model. Earth Planet. Sci. Lett. 295, 451-461.

Pollack, H.N., Hurter, S.J., Johnson, J.R., 1993. Heat-flow from the Earth's interior analysis of the global data set. Rev. Geophys. 31, 267-280.

Pritchard, H.D., Ligtenberg, S.R.M., Fricker, H.A., et al., 2012. Antarctic ice-sheet loss driven by basal melting of ice shelves. Nature 484, 502-505.

Rignot, E., Mouginot, J., Scheuchl, B., et al., 2019. Four decades of Antarctic Ice Sheet mass balance from 1979-2017. Proc. Natl. Acad. Sci. U. S. A. 116, 1095-1103.

Robel, A.A., DeGiuli, E., Schoof, C., Tziperman, E., 2013. Dynamics of ice stream temporal variability: modes, scales, and hysteresis. J. Geophys. Res. Earth Surf. 118, 925-936.

Rudnick, L.R., McDonough, W.F., O'Connell, R.J., 1998. Thermal structure, thickness and composition of continental lithosphere. Chem. Geol. 145, 395-411.

Sachs, J., Anderson, R., 2005. Increased productivity in the SubAntarctic ocean during Heinrich events. Nature 434, 1118-1121.

Salamatin, A.N., Lipenkov, V.Y., Barkov, N.I., et al., 1998. Ice core age dating and paleothermometer calibration based on isotope and temperature profiles from deep boreholes at Vostok Station (East Antarctica). J. Geophys. Res. 103 (D8), 8963-8977.

Schröeder, D.M., Blankenship, D.D., Young, D.A., Quartini, E., 2014. Evidence for elevated and spatially variable geothermal flux beneath the West Antarctic ice sheet. Proc. Natl. Acad. Sci. U. S. A. 111, 9070-9072.

Shapiro, N.M., Ritzwoller, M.H., 2004. Inferring surface heat flux distributions guided by a global seismic model: particular application to Antarctica. Earth Planet. Sci. Lett. 223, 213-224.

Shen, W., Wiens, D.A., Lloyd, A.J., Nyblade, A.A., 2020. A geothermal heat flux map of Antarctica empirically constrained by seismic structure. Geophys. Res. Lett. 47 e2020GL086955.

Shepherd, A., Ivins, E., Rignot, E., IMBIE Team, 2018. Mass balance of the Antarctic Ice Sheet from 1992 to 2017. Nature 558, 219-222.

Siegert, M.J., Dowdeswell, J.A., 1996. Spatial variations in the heat at the base of the Antarctic Ice Sheet from analysis of the thermal regime above sub-glacial lakes. J. Glaciol. 42, 501-509.

Stål, T., Reading, A.M., Halpin, J.A., Whittaker, J.M., 2020. Antarctic geothermal heat flow model: Aql, Geochem. Geophys, Geosyst, 22 e2020GC009428. 
Studinger, M., Karner, G.D., Bell, R.E., et al., 2003. Geophysical models for the tectonic framework of the Lake Vostok region, East Antarctica. Earth Planet. Sci. Lett. 216, 663-677.

Talalay, P., Li, Y., Augustin, L., et al., 2020. Geothermal flux beneath the Antarctic Ice Sheet derived from measured temperature profiles in deep boreholes. Cryosphere. https://doi.org/10.5194/tc-2020-32. van Wijk, J.W., Lawrence, J.F., Driscoll, N.W., 2008. Formation of the Transantarctic Mountains related to extension of the West Antarctic rift system. Tectonophysics 458, 117-126.

WAIS Divide Project Members, 2013. Onset of deglacial warming in West Antarctica driven by local orbital forcing. Nature 500, 440-444. 